Prepared in cooperation with U.S. Army Corps of Engineers and Lower Minnesota River Watershed District

\title{
Estimation of Suspended Sediment at a Discontinued Streamgage on the Lower Minnesota River at Fort Snelling State Park, Minnesota
}

Open-File Report 2021-1005 



\section{Estimation of Suspended Sediment at a Discontinued Streamgage on the Lower Minnesota River at Fort Snelling State Park, Minnesota}

By Joel T. Groten, Jon S. Hendrickson, and Linda R. Loomis

Prepared in cooperation with U.S. Army Corps of Engineers and Lower Minnesota River Watershed District

Open-File Report 2021-1005 


\section{U.S. Geological Survey, Reston, Virginia: 2021}

For more information on the USGS - the Federal source for science about the Earth, its natural and living resources, natural hazards, and the environment—visit https://www.usgs.gov or call 1-888-ASK-USGS.

For an overview of USGS information products, including maps, imagery, and publications, visit https://store.usgs.gov/.

Any use of trade, firm, or product names is for descriptive purposes only and does not imply endorsement by the U.S. Government.

Although this information product, for the most part, is in the public domain, it also may contain copyrighted materials as noted in the text. Permission to reproduce copyrighted items must be secured from the copyright owner.

Suggested citation:

Groten, J.T., Hendrickson, J.S., and Loomis, L.R., 2021, Estimation of suspended sediment at a discontinued streamgage on the lower Minnesota River at Fort Snelling State Park, Minnesota: U.S. Geological Survey Open-File Report 2021-1005, 12 p., https://doi.org/10.3133/ofr20211005.

Associated data for this publication:

Groten, J.T., 2021, Suspended-sediment and sand concentrations, streamflow, acoustic data, linear regression models, and loads for the Lower Minnesota River, 2012 -2019: U.S. Geological Survey data release, https://doi. org/10.5066/P9AIULO0.

U.S. Geological Survey, 2020, USGS water data for the Nation: U.S. Geological Survey National Water Information System database, https://doi.org/10.5066/F7P55KJN.

ISSN 2331-1258 (online) 


\section{Acknowledgments}

This report presents a compilation of information, resources, and expertise supplied by many agencies and individuals. The authors would like to thank the U.S. Army Corps of Engineers and Lower Minnesota River Watershed District for their assistance with this study.

Gerald Storey, J. William Lund, and Erin Coenen of the U.S. Geological Survey are acknowledged for assistance with equipment installation, maintenance, field sampling, and data management. Aliesha Krall and Cassi Crow of the U.S. Geological Survey are acknowledged for their technical reviews of the report. 



\section{Contents}

Acknowledgments ……...................................................................................................................

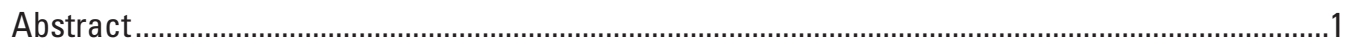

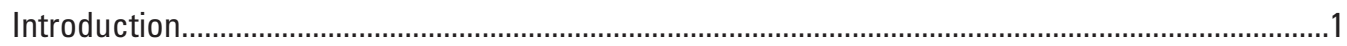

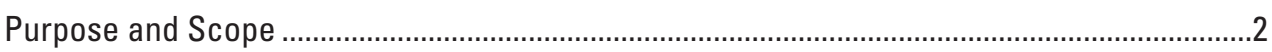

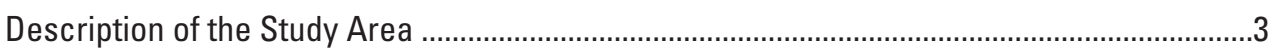

Methods of Data Collection and Analysis ………..................................................................

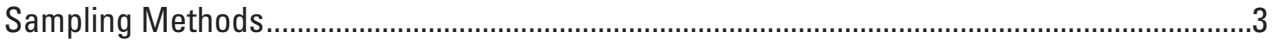

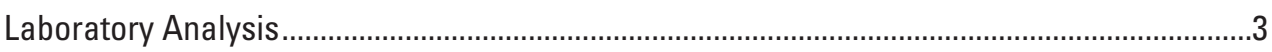

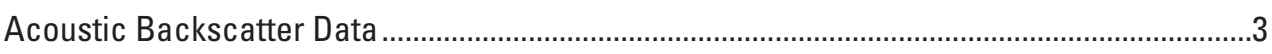

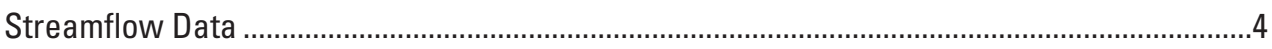

Statistical Analysis for Suspended-Sediment Models ............................................................

Development of Linear Regression Models .................................................................4

Daily and Annual Suspended-Sediment Load Estimates...................................................4

Models to Estimate Suspended-Sediment and Sand Concentrations...............................................

Suspended-Sediment Concentration Models ............................................................................5

Suspended-Sand Concentration Models ..................................................................................

Estimation of Suspended-Sediment Loads .............................................................................

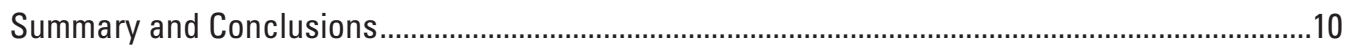

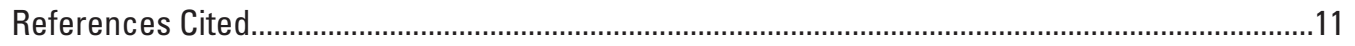

\section{Figures}

1. Map showing location of the study area and sampling sites in the Minnesota River Basin ....................................................................................................................

2. Graphs showing streamflow at two sites and mean sediment-corrected backscatter at one site on the lower Minnesota River ....................................................6

3. Graphs showing relations among suspended-sediment concentrations and mean sediment corrected backscatter at two sites on the lower Minnesota River.........8

4. Graph showing relations among suspended-sediment concentrations and streamflow at the Minnesota River at Fort Snelling State Park, Minnesota ......................8

5. Graph showing relations among suspended-sand concentrations and streamflow at the Minnesota River at Fort Snelling State Park, Minnesota

6. Graph showing estimated annual suspended-sediment loads from acoustic backscatter at two sites on the lower Minnesota River, water years 2018 through 2019

7. Graph showing estimated annual suspended-sediment loads from streamflow at the Minnesota River at Fort Snelling, water years 2018 through 2019 .......................10

8. Graph showing estimated annual suspended-sand loads from streamflow at the Minnesota River at Fort Snelling, water years 2018 through 2019.

\section{Tables}

1. Summary of linear regression models for two sites on the lower Minnesota River, water years 2012 through 2019 


\section{Conversion Factors}

U.S. customary units to International System of Units

\begin{tabular}{lcl}
\hline \multicolumn{1}{c}{ Multiply } & By & \multicolumn{1}{c}{ To obtain } \\
\hline mile $(\mathrm{mi})$ & Length & \\
\hline & 1.609 & kilometer $(\mathrm{km})$ \\
\hline pint $(\mathrm{pt})$ & Volume & \\
quart $(\mathrm{qt})$ & 0.4732 & liter $(\mathrm{L})$ \\
\hline & 0.9464 & liter $(\mathrm{L})$ \\
\hline cubic foot per second $(\mathrm{ft} 3 / \mathrm{s})$ & Flow rate & \\
\hline & 0.02832 & cubic meter per second $\left(\mathrm{m}^{3} / \mathrm{s}\right)$ \\
\hline ton, short $(2,000 \mathrm{lb})$ & Mass & \\
\hline
\end{tabular}

International System of Units to U.S. customary units

\begin{tabular}{|c|c|c|}
\hline Multiply & By & To obtain \\
\hline \multicolumn{3}{|c|}{ Volume } \\
\hline liter $(\mathrm{L})$ & 2.113 & pint (pt) \\
\hline liter (L) & 1.057 & quart (qt) \\
\hline millimeter (mm) & 0.03937 & inch (in.) \\
\hline
\end{tabular}

\section{Supplemental Information}

Concentrations of physical constituents in water are given in milligrams per liter (mg/L).

Water year (WY) is the 12-month period, October 1 through September 30, and is designated by the calendar year in which it ends. 


\section{Abbreviations}

$\begin{array}{ll}\text { ADVM } & \text { acoustic Doppler velocity meter } \\ \text { EDI } & \text { equal-discharge increment } \\ \text { EWI } & \text { equal-width increment } \\ \text { LMWD } & \text { Lower Minnesota River Watershed District } \\ p \text {-value } & \text { probability value } \\ \text { SCB } & \text { sediment-corrected backscatter } \\ \text { SLR } & \text { simple linear regression } \\ \text { SSC } & \text { suspended-sediment concentration } \\ \text { SSL } & \text { suspended-sediment load } \\ \text { USACE } & \text { U.S. Army Corps of Engineers } \\ \text { USGS } & \text { U.S. Geological Survey } \\ \text { WY } & \text { water year }\end{array}$





\title{
Estimation of Suspended Sediment at a Discontinued Streamgage on the Lower Minnesota River at Fort Snelling State Park, Minnesota
}

\author{
By Joel T. Groten, ${ }^{1}$ Jon S. Hendrickson, ${ }^{2}$ and Linda R. Loomis ${ }^{3}$
}

\section{Abstract}

In the spring of 2019, ice sheets transported downstream during a large streamflow rise event in the lower Minnesota River destroyed an index-velocity streamgage at the Minnesota River at Fort Snelling State Park, Minnesota (U.S. Geological Survey station 05330920; hereafter referred to as "Ft. Snelling"). The streamgage previously used an acoustic Doppler velocity meter to provide instantaneous streamflow and suspended-sedimentation concentration (SSC) data in backwater conditions caused by the confluence with the Mississippi River. In response, the U.S. Geological Survey cooperated with the U.S. Army Corps of Engineers and Lower Minnesota River Watershed District to develop linear regression models that estimate SSCs and suspended-sand concentrations (sand) at the destroyed streamgage using streamflow data from an upstream site Minnesota River near Jordan, Minn. (U.S. Geological Survey station 05330000, hereafter referred to as "Jordan").

Simple linear regression models were developed for selected positions on the streamflow hydrograph to estimate SSC and sand at Ft. Snelling from the streamflow at Jordan. Statistically significant models could not be developed for estimating SSC at low streamflows and sand at high streamflows. Models developed to estimate sand were more uncertain than models used to estimate SSC, and models using streamflow to predict SSC and sand were more uncertain than models using acoustic backscatter to predict SSC. Annual loads of SSC and sand estimated from these models show the dynamic nature of sediment transport and storage in this section of the lower Minnesota River. These models and the associated ancillary data can help with management decisions that are crucial in managing aquatic habitat, supporting power production, and commercial navigation.

\footnotetext{
${ }^{1}$ U.S. Geological Survey.

2U.S. Army Corps of Engineers.
}

${ }^{3}$ Lower Minnesota Watershed District.

\section{Introduction}

The U.S. Army Corps of Engineers (USACE) and Lower Minnesota Watershed District (LMWD) have a strong interest in knowing and understanding the streamflow and suspendedsediment load (SSL) in the lower Minnesota River. Excessive sediment leads to increased navigation channel dredging, which is expensive to remove and store, reduces recreational opportunities, can transport harmful contaminants, and is deleterious to aquatic habitat (U.S. Army Corps of Engineers, 2006; Minnesota Pollution Control Agency, 2009). The USACE maintains the commercial navigation channels by dredging sand in the lower 14.7 miles of the Minnesota River upstream from the confluence with the Mississippi River and the upper portion of the Mississippi River downstream from the confluence with the Minnesota River (fig. 1; U.S. Army Corps of Engineers, 2001, 2007, 2011). The LMWD is responsible for removing and storing sand material dredged from the Minnesota River. The USACE, LMWD, and U.S. Geological Survey (USGS) worked in cooperation on this project, and USGS sampled suspended sediment along the lower Minnesota River from 2011 through 2019 to support management of dredging operations.

Streamgages are extremely important for planning, forecasting, and warning communities about floods. Streamflow monitoring also helps water-resource managers deal with other water-related issues, such as environmental conditions for aquatic habitat, designing structures, and operation of waterways to support power production and navigation. Sediment data are not collected as frequently as streamflow data across the Nation, but understanding the role of sediment in our waterways is important because excess sediment can cause many environmental and economic challenges. The Minnesota River at Fort Snelling State Park, Minnesota, (USGS station 05330920; hereafter referred to as "Ft. Snelling") streamgage was used for all these purposes prior to being destroyed by ice sheets during a spring flood in 2019, and the streamgage will not be replaced because of budget constraints.

Although the Ft. Snelling streamgage will not be replaced, water-resource managers still need to understand how much sediment is transported through the lower 
Minnesota River. This study leveraged previous studies carried out along the lower Minnesota River to provide estimates of suspended sediment when the Ft. Snelling streamgage was inoperable. In the first study (Groten and others, 2016), suspended-sediment, bedload, and particle-size samples were collected in the lower Minnesota River Basin during water years (WYs) 2011 through 2014. In addition, surrogate measurements of acoustic backscatter were collected at Ft. Snelling during WYs 2012 through 2016 to improve understanding of sediment-transport relations by quantifying sediment and suspended-sediment loads. Annual sediment loads were computed for calendar years 2011 through 2014.

In the second study (Groten and others, 2019), suspended-sediment concentrations (SSCs) and acoustic backscatter data were collected using acoustic Doppler velocity meters (ADVMs) during a 2-year period. Annual SSLs were computed for WYs 2016 and 2017. These two previous studies provided most of the information needed to estimate SSLs at Ft. Snelling from the streamflow at the Minnesota River near Jordan, Minn. (U.S. Geological Survey station 05330000, hereafter referred to as "Jordan").
An ADVM was used to measure sediment at Ft. Snelling (Groten and others, 2016, 2019) because sediment estimates from acoustic backscatter surrogates are less affected by hysteresis compared to sediment estimates from streamflow, and ADVMs could provide continuous SSCs that can be used to monitor and understand complex sediment transport (Gray and Gartner, 2009). Hysteresis can be seen in the relation between streamflow and SSC because streamflow does not always adequately represent changes in SSC, which can vary for the same streamflows (Landers and Sturm, 2013). Additionally, using an ADVM to measure sediment can reduce long-term monitoring costs (Wood, 2014). Because the ADVM was destroyed at Ft. Snelling, alternate methods would need to be used to estimate SSC from available streamflow.

\section{Purpose and Scope}

The purpose of this report is to summarize and interpret collected SSCs, suspended-sand concentrations (sand), acoustic backscatter, and streamflow data to provide estimates of SSLs for the lower Minnesota River and improve understanding of sediment-transport processes. Specifically, the

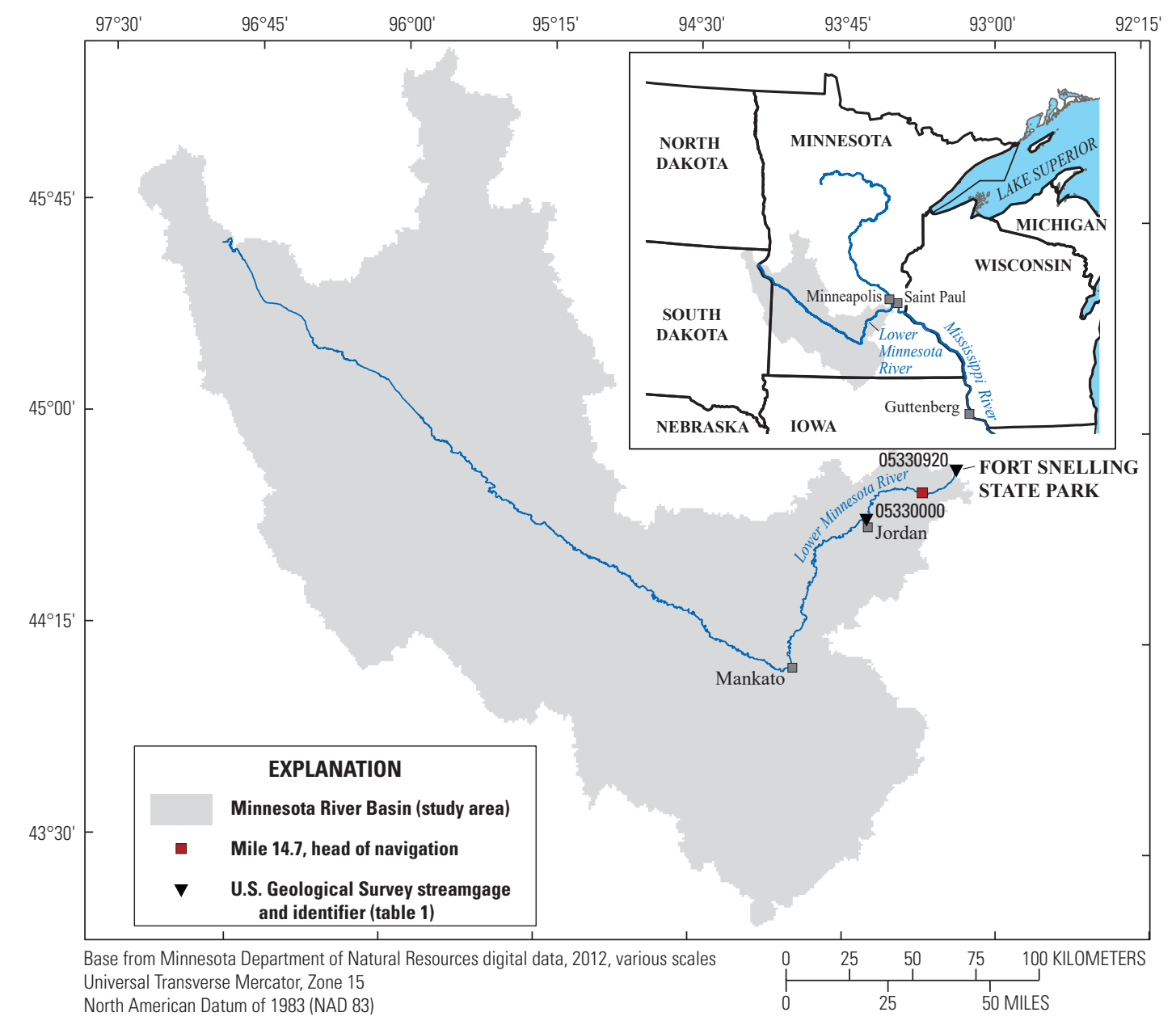

Figure 1. Location of the study area and sampling sites in the Minnesota River Basin. 
report describes (1) the relations among SSC, sand, acoustic backscatter, and streamflow in the lower Minnesota River for WYs 2012 through 2019 and (2) annual SSLs for WYs 2018 and 2019.

\section{Description of the Study Area}

The lower Minnesota River is a major source of sediment to the Mississippi River (Engstrom and others, 2009; Minnesota Pollution Control Agency, 2015). The study area (fig. 1) is described in detail by Groten and others (2016; 2019). The two sediment-monitoring sites sampled during the study were Jordan and Ft. Snelling. The sampling sites are approximately 37 river miles apart; there are no substantial river tributary inflows between Jordan and Ft. Snelling, but stormwater sewers drain into the river between the two sites. The contribution of sediment from stormwater was not further investigated in this report because of limited financial resources. To accurately capture the stormwater contribution to the lower Minnesota River, multiple sites would have needed to be established between Jordan and Ft. Snelling. The site at Ft. Snelling measured the gross sediment load from the lower Minnesota River, and without additional monitoring sites the sediment contribution from stormwater could not be determined.

The stretch of the lower Minnesota River between Jordan and Ft. Snelling has been documented to be a depositional area or net sink for sediment (Groten and others, 2016) and a source of sediment (Groten and others, 2019) depending on interactions between sediment concentrations and streamflows in the Minnesota and Mississippi Rivers. The site of the former Ft. Snelling streamgage is affected by backwater from the confluence with Mississippi River downstream. This section of the lower Minnesota River has a large flood plain and sloughs, and the gradient flattens moving downstream towards the confluence with the Mississippi River (Groten and others, 2019). These features provide potential for sediment storage in the flood plain, sloughs, and channel. The lower Minnesota River has also been documented as a source of sediment, with the channel widening 52 percent and shortening by 7 percent since 1938 (Lenhart and others, 2013).

\section{Methods of Data Collection and Analysis}

Suspended-sediment samples were collected at established USGS streamgages over a range of observed streamflows when the river was not covered by ice (open-water season) at each site. Jordan was sampled for SSCs during WYs 2016 through 2019, and Ft. Snelling was sampled for SSCs during WYs 2012 through 2018. Corresponding acoustic backscatter data were collected during SSC sample collection at both sites. Collected samples were analyzed for SSC and percentage of fines, which were used to calculate sand and will be explained in the "Laboratory Analysis" section.

\section{Sampling Methods}

Water samples for analysis of SSC were collected using isokinetic samplers and depth-integrating techniques at equal-width increments (EWIs) or equal-discharge increments (EDIs; Edwards and Glysson, 1999; Davis, 2005; Groten and others, 2019). For collection of water samples, the stream width was either divided into 10 EWIs or 5 EDIs for sample collection. Each isokinetic, depth-integrated sample was collected at the centroid of each increment according to procedures in Edwards and Glysson (1999). Depending on the river depth and velocity, samples from each centroid were collected from the stream transect with a D-74 or D-96 sampler (Davis, 2005) lined with either a 1-pint glass bottle, a 1-quart glass bottle, or a 3-liter bag. Each sample collected from all the centroids of the stream transect were composited into one sample for analysis.

\section{Laboratory Analysis}

Water samples were analyzed for SSC following method D3977-97 (Guy, 1969; American Society for Testing and Materials, 2000) by the USGS Sediment Laboratory in Iowa City, Iowa. Percentages of fines also were determined for SSC samples at the same laboratory by wet sieving (Guy, 1969). Fines are defined as particle sizes, clay and silt, less than 0.0625 millimeter $(\mathrm{mm})$. Particles that measure greater than or equal to $0.0625 \mathrm{~mm}$ to $2.0 \mathrm{~mm}$ are sands. The sands were calculated by taking the percentage of fines and multiplying it by the corresponding SSC value, dividing the product by 100 , and subtracting the quotient from the SSC value. Results from laboratory analyses are available in a USGS data release (Groten, 2021) and at the USGS National Water Information System web page (U.S. Geological Survey, 2020).

\section{Acoustic Backscatter Data}

Acoustic Doppler velocity meters (ADVMs) were deployed at both sampling sites (fig. 1). The configuration, programming, and corrections of ADVMs are explained in detail by Groten (2018), Groten and others (2019), and Groten (2021). Acoustic backscatter data were adjusted through three separate corrections: (1) attenuation of the acoustic signal because of beam spreading, (2) acoustic absorption by water, and (3) attenuation of the acoustic signal by suspended sediment (Landers and others, 2016). The acoustic surrogate metric produced by these corrections was mean sedimentcorrected backscatter (SCB; Landers and others, 2016), in decibels, which was used as an explanatory variable for SSC 
in the development of two linear regression models. Data generated during this study are available in a USGS data release (Groten, 2021).

\section{Streamflow Data}

Suspended-sediment samples for this study were collocated at established streamgages (fig. 1). Instantaneous and daily mean streamflow data are available at the USGS National Water Information System web page (U.S. Geological Survey, 2020). Instantaneous streamflow values were graphically categorized by documenting positions on the streamflow hydrograph, which were used to partition the data to minimize the effects of hysteresis for the development of models that used streamflow at Jordan to estimate SSC and sand at Ft. Snelling.

\section{Statistical Analysis for Suspended-Sediment Models}

Previous studies had already established a series of linear regression models to estimate SSCs from SCB in the lower Minnesota River (Groten, 2018; Groten and others, 2019). Newly collected data were used to update two of these models and develop new models for estimating suspended sediment and sand loads at Ft. Snelling. Data analyses included the development of linear regression models and the computation of daily and annual SSL estimates (Groten, 2021). Data analyses also included the identification of outliers (Groten, 2021) in the datasets. Sample outliers can happen during sample collection when the streambed is inadvertently sampled because the sampler disturbed and entrained deposited bed sediment or when the sampler nozzle accidentally contacted a sand dune. Identified outliers were removed before data analysis (Groten, 2021).

\section{Development of Linear Regression Models}

The suitability of surrogate relations was tested at each site by completing ordinary least squares regression analyses (Helsel and others, 2020) using an acoustic metric (SCB) and streamflow as explanatory variables and SSC and sand as the response variables. Existing acoustic models estimating SSC at Jordan and Ft. Snelling were redeveloped from Groten (2018) and Groten and others (2019) with additional data collected during this study from Jordan and Ft. Snelling (Groten, 2021). New models estimating SSC and sands at Ft. Snelling were developed based on streamflow at Jordan. Streamflow at Jordan was divided into five categories based on hydrograph position: low, rise, peak, high (greater than 20,000 cubic feet per second $\left[\mathrm{ft}^{3} / \mathrm{s}\right]$ ), and falling, which resulted in 4 SSC models and 4 sand models. Different combinations of simple linear regressions (SLRs) on untransformed and transformed data were tested. A level of significance $(\alpha)$ of 0.05 was used for all statistical analyses presented in this study.

The Surrogate Analysis and Index Developer (Domanski and others, 2015) was used to update regression models developed by Groten (2018) and Groten and others (2019) and evaluate the accuracy of developed models for estimating SSCs and sand. Diagnostic plots, residual errors, and probability values ( $p$-values) were examined to ensure models met the assumptions of ordinary least squares regression analyses (Helsel and others, 2020; Groten, 2021). Streamflow, sand, and SSC were log transformed (base-10 logarithms), whereas SCB was not, and bias-correction factors were applied (Duan, 1983) after the data were retransformed into the original units (Groten, 2021). The final linear regression models were used to generate a time series of estimated SSC and sand values and prediction intervals (Helsel and others, 2020; Groten, 2021). The following model form was used to predict SSC and sand:

$$
S S C \text { or } \text { Sand }=10^{b_{0}+b_{1} x_{1}} \times B C F
$$

where
SSC is suspended-sediment concentration, in milligrams per liter;
Sand is suspended-sand concentration, in milligrams per liter;
$b_{0} \quad$ is the intercept;
$b_{1} \quad$ is the slope for the first explanatory variable;
$x_{1} \quad$ is the first explanatory variable; and
$B C F \quad$ is the bias-correction factor (Duan, 1983).

The resulting linear regression models were then used to estimate daily SSL and suspended-sand load as described in the next section.

\section{Daily and Annual Suspended-Sediment Load Estimates}

Daily mean SSC and sand estimates and 90-percent prediction intervals were calculated from the final linear regression models, and daily SSLs were estimated using the following equation (Porterfield, 1972):

$$
S S L \text { or } \operatorname{Sand} L=Q \times S S C \text { or } \operatorname{Sand} \times c_{f}
$$

where

SSL is the daily mean suspended-sediment load, in tons per day;

SandL is the daily mean suspended-sand load, in tons per day;

$Q \quad$ is the daily mean streamflow, in cubic feet per second;

SSC is the daily mean suspended-sediment concentration, in milligrams per liter;

Sand is the daily mean suspended-sand concentration, in milligrams per liter; and 
$c_{f} \quad$ is a coefficient $(0.0027)$ that converts the units of streamflow and SSC into tons per day and assumes a specific gravity of 2.65 for sediment.

Loads were calculated by inputting daily mean streamflow at Jordan into the hydrograph-position models that estimated SSC or sand from the streamflow condition from which the model was developed. The model estimate was then multiplied by the daily mean streamflow at Ft. Snelling. Below are the streamflow conditions for applying the hydrographposition models.

1. If a value was less than $2,500 \mathrm{ft} 3 / \mathrm{s}$, then it was classified as "low."

2. If a value was greater than $20,000 \mathrm{ft}^{3} / \mathrm{s}$, then it was classified as "high."

3. If a value was greater than the previous value, then it was classified as "rise."

4. If a value was equal to the previous value, then it was classified as "peak."

5. If a value was less than the previous value, then it was classified as "fall."

The falling model was used to estimate SSC loads at the low category, and median sand value for the high category was used to estimate sand loads at the high category because statistically significant models could not be developed.

\section{Models to Estimate Suspended-Sediment and Sand Concentrations}

Further analysis of the SCB (SSC surrogate) at Ft. Snelling indicated that the SCB usually peaks prior to the streamflow peak at Ft. Snelling and peaked closer to the streamflow peak at Jordan (fig. 2); therefore, Jordan streamflow was used to estimate SSC and sand at Ft. Snelling.
Eight models were developed to estimate SSC and sand at Ft. Snelling using data on different positions of the streamflow hydrograph from Jordan.

\section{Suspended-Sediment Concentration Models}

Two SLR models that estimated SSC from SCB (acoustic - SSC models) were updated from Groten (2018) and Groten and others (2019) to include data from 2018 and 2019 at Jordan and 2018 at Ft. Snelling (table 1; fig. 3). When comparing the original models developed from Groten (2018) and Groten and others (2019) to the updated models, the coefficients did not change substantially at Ft. Snelling; however, the equation slope of the updated model at Jordan decreased by 0.02 from that of the original model. The updated Jordan model also has more variance than the original model, which might be explained by different sampling methods used during this study. Some of the samples at the Jordan site were collected using the EWI method from the downstream side of the bridge, whereas other samples were collected downstream from the bridge from a boat using the EDI method.

During hydrograph-position model development, a statistically significant SSC model could not be produced for the low category because of a poor relation between SSC and streamflow. Comparing the four streamflow-SSC models (table 1; fig. 4) that were developed, the equation slope was positive for three of the models and negative for one of the models (table 1). The steepest positive slope was on the model developed for the rise category, followed by a slight 0.04 decrease in slope for the peak category, and followed by a 0.18 decrease in slope for the falling category. The model with a negative slope was the high (greater than 20,000 ft3/s) category. The negative slope is likely caused by the streamflow approaching and exceeding bankfull streamflow $\left(28,500 \mathrm{ft}^{3} / \mathrm{s}\right.$; Ellison and others, 2016) and (or) backwater effects from the Mississippi River, which reduce the velocities of the water and cause sediment to fall out of suspension. 


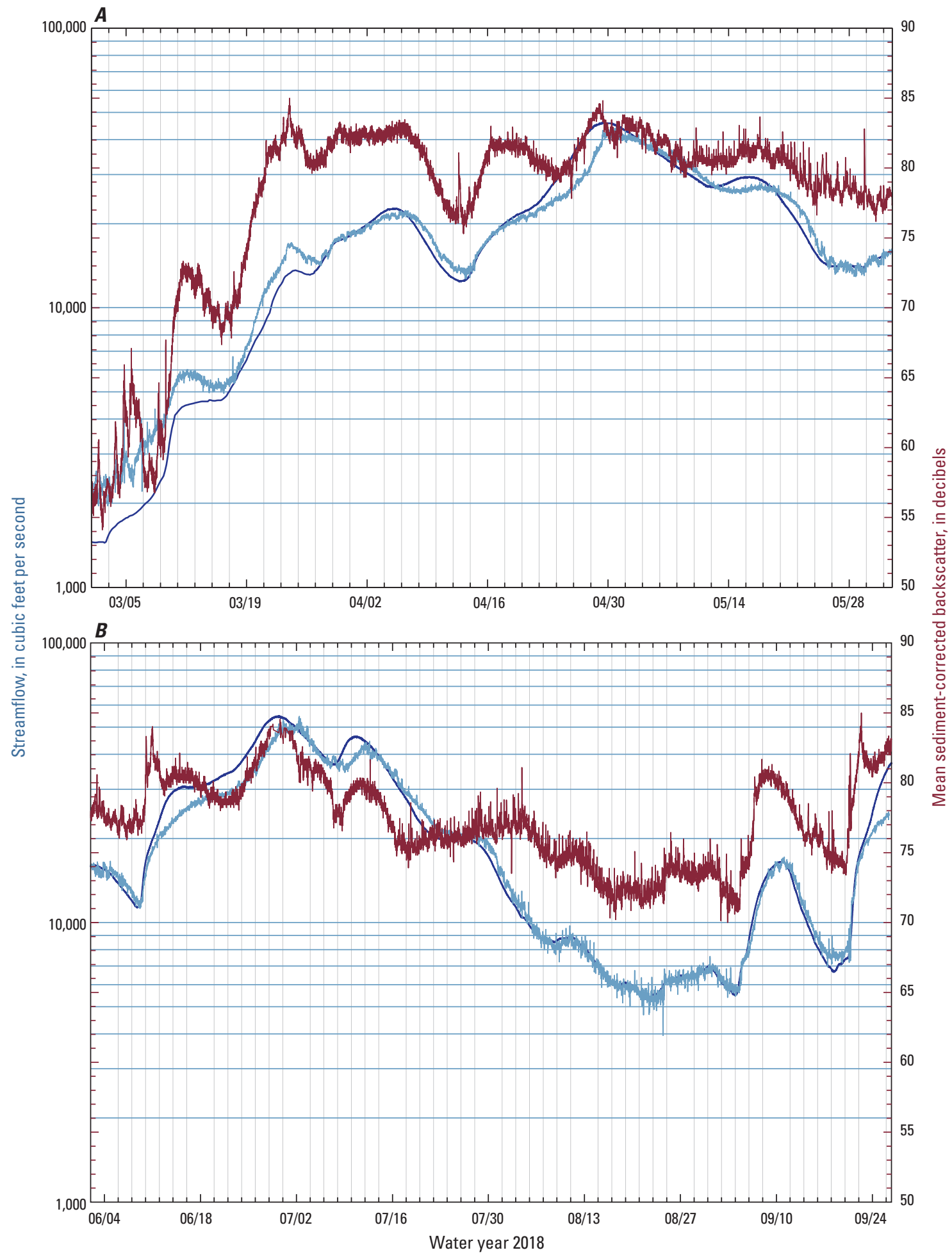

EXPLANATION

Mean sediment-corrected backscatter at the Minnesota River at Fort Snelling

Streamflow at the Minnesota River near Jordan

Streamflow at the Minnesota River at Fort Snelling

Figure 2. Streamflow at two sites (U.S. Geological Survey stations 05330920 and $05330000 ;$ U.S. Geological Survey, 2020) and mean sediment-corrected backscatter at one site (U.S. Geological Survey station 05330920) on the lower Minnesota River. A, March through May, water year 2018. B, June through September, water year 2018. 


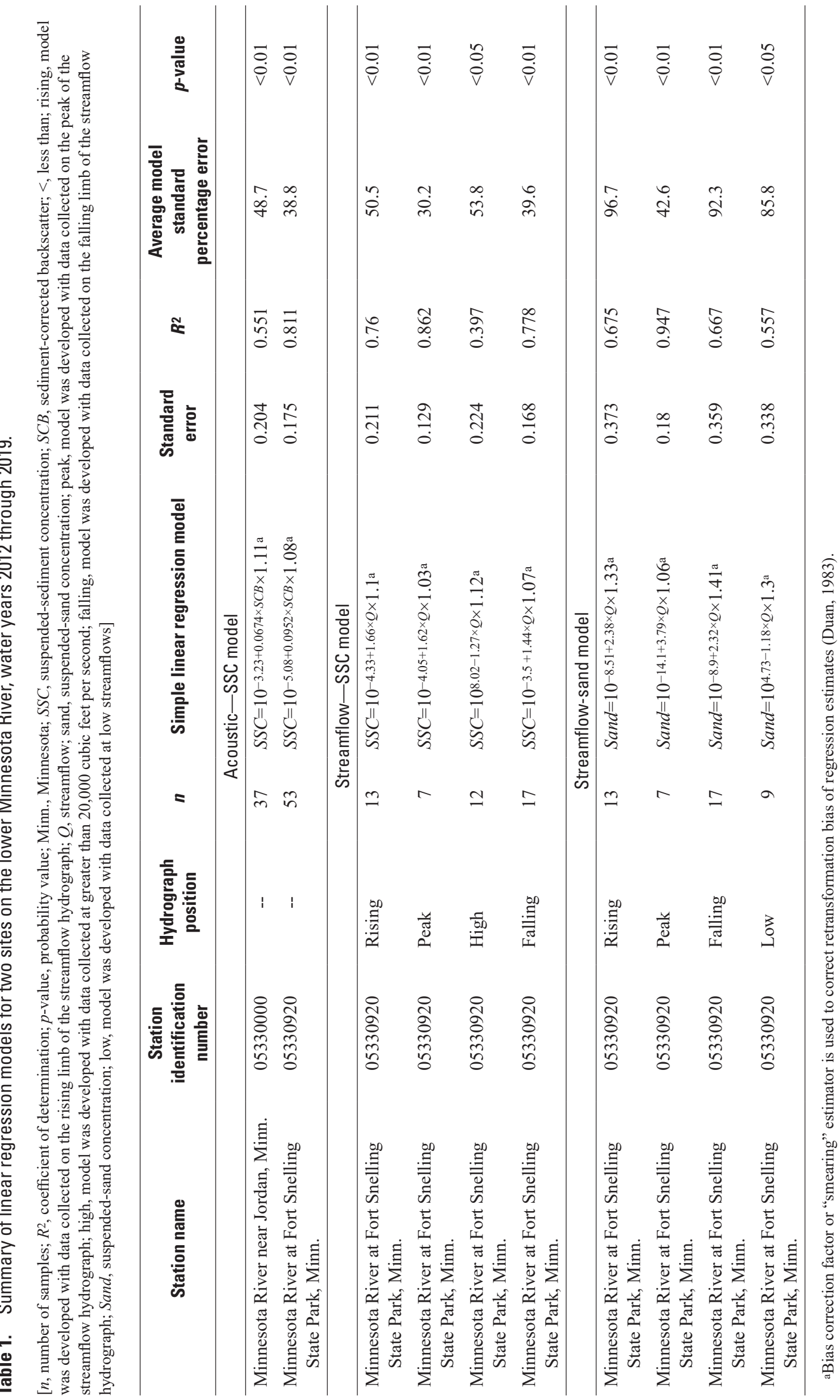



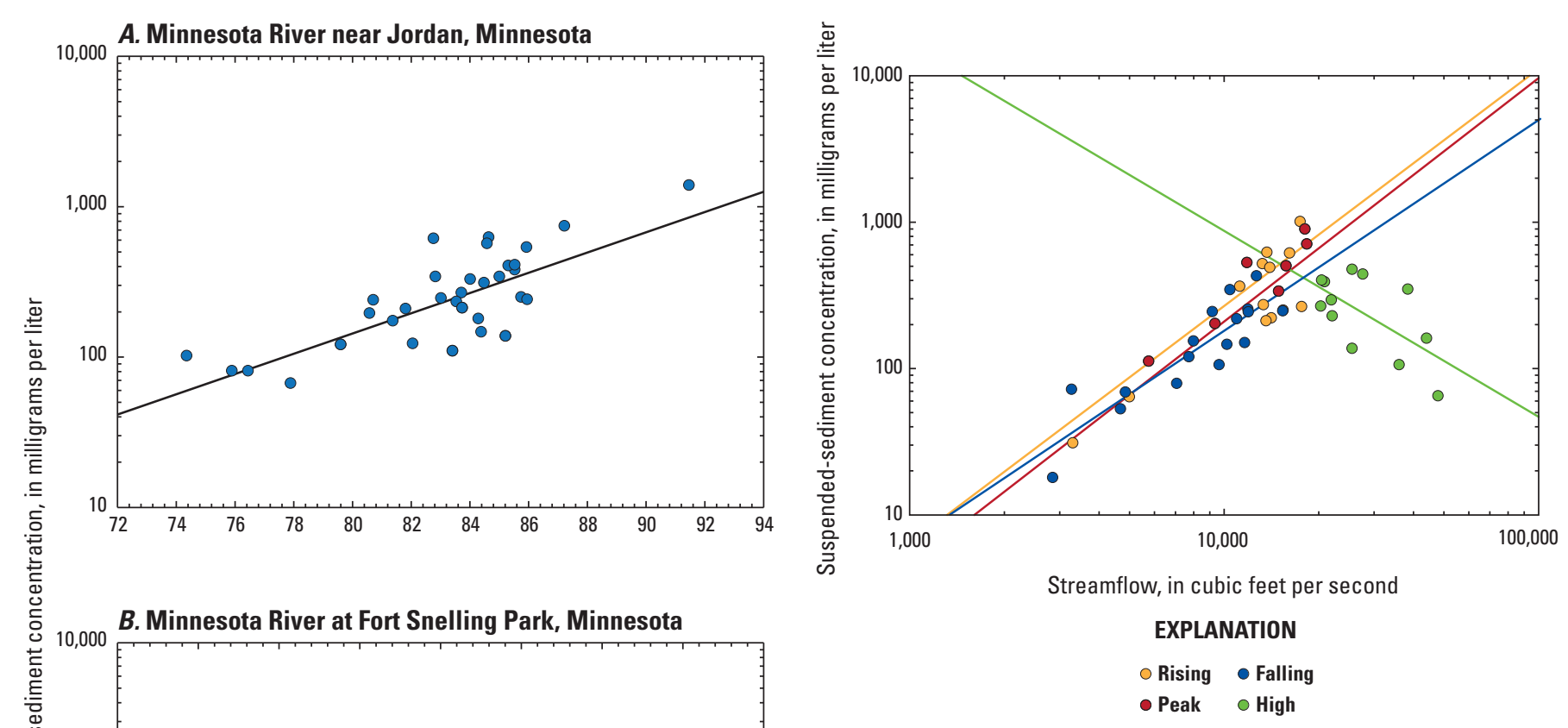

Figure 4. Relations among suspended-sediment concentrations and streamflow at the Minnesota River at Fort Snelling State Park, Minnesota.

Figure 3. Relations among suspended-sediment concentrations and mean sediment corrected backscatter at two sites on the lower Minnesota River. A, Minnesota River near Jordan, Minnesota, (U.S. Geological Survey station 05330000). B, River at Fort Snelling State Park, Minnesota (U.S. Geological Survey station 05330920). 


\section{Suspended-Sand Concentration Models}

The same streamflow categories (low, rise, peak, high, and falling) at Jordan were used to develop SLR models to estimate sands (sand-SSC models) at Ft. Snelling (table 1; fig. 5). During model development, a statistically significant model could not be produced for the high category possibly because of streamflows exceeding bankfull, accessing the flood plain, entering sloughs, and resulting in sand deposition. The four suspended-sand models that were developed were similar to the streamflow models that estimated SSC in that the slope was positive for three of the models and negative for one of the models. However, the slopes were different with the steepest positive slope being the peak category, followed by a 1.41 slope decrease on the rise category, and followed by a slight 0.06 decrease in slope for the falling category. The peak category transported greater concentrations of sands than all the other categories. The low-category model had a negative slope for this constituent. The negative slope likely results from the low energy of streamflows at low flows and the inability to keep the heavier sand-sized particles in suspension.
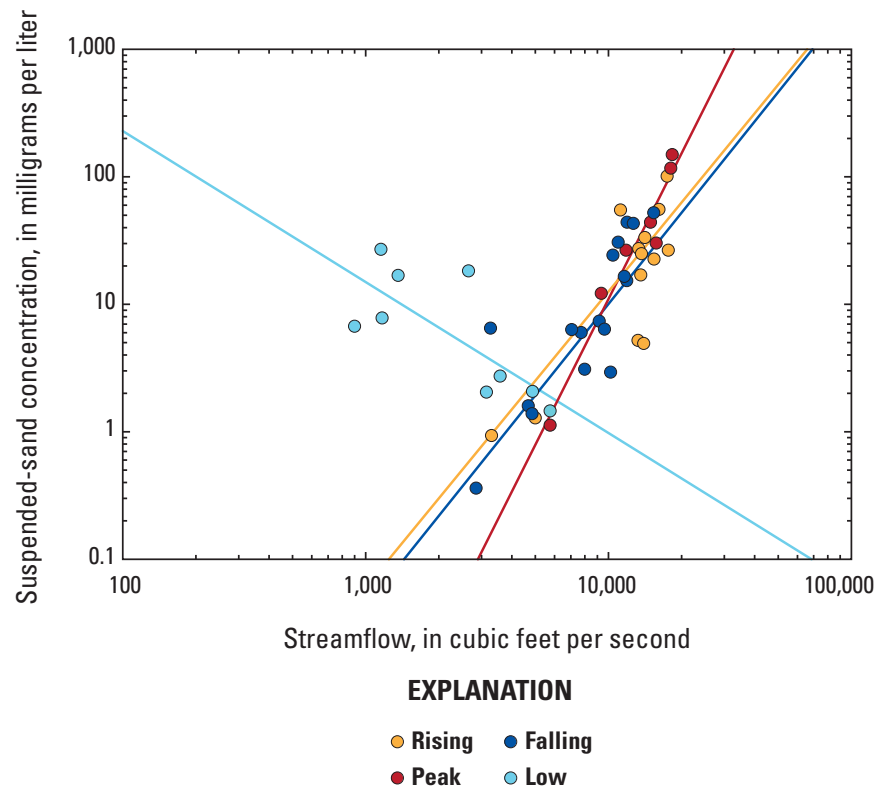

Figure 5. Relations among suspended-sand concentrations and streamflow at the Minnesota River at Fort Snelling State Park, Minnesota.

\section{Estimation of Suspended-Sediment Loads}

When comparing SSLs estimated from acoustic backscatter and streamflow position on the hydrograph, the streamflow-based estimates were greater than acoustic-based estimates (Groten, 2021; figs. 6 and 7). All models developed in this study have relatively high variance and are affected by hysteresis (Groten and others, 2016; Topping and Wright, 2016; Groten and others, 2019), which affects the accuracy of the results, but the estimates from the ADVMs are assumed to be more accurate because backscatter is more of a direct measure of sediment than streamflow. If this assumption is true, the load estimates from the streamflow hydrograph position may be overestimated with a greater overall range in prediction intervals (figs. 7 and 8). Annual sand loads are shown in figure 8. The measured streamflows in the lower Minnesota River in 2018 and 2019 were historically high, with 2018 being the fourth highest and 2019 being the highest average annual flow during period of record (U.S. Geological Survey, 2020). Because streamflows were high, loads were also high.

Groten and others (2016) documented a decrease (sink) in sediment loading between Jordan and Ft. Snelling, but an increase in loading from Jordan to Ft. Snelling was observed in Groten and others (2019). Loads in Groten and others (2016) were estimated from streamflow, whereas loads in Groten and others (2019) were estimated from acoustic metrics. The SSL estimates from these two studies are challenging to compare because of the different methods, SCB and streamflow, used in estimating SSC.

In WY 2018, the acoustic method was used at Jordan and Ft. Snelling because ADVMs were operational at both sites. Estimated SSLs computed from acoustic data in WY 2018 showed a decrease in SSL from Jordan to Ft. Snelling. There was an increase in SSLs when using the acoustic method at Jordan and the streamflow method at Ft. Snelling during WYs 2018 and 2019. The results indicate a discrepancy in WY 2018. A decrease in SSL between the two sites was observed when the acoustic method was used at both sites, and an increase in SSL between the two sites was observed when the acoustic method was used at Jordan and the streamflow method was used at Ft. Snelling. Streamflow models likely overestimated SSCs and subsequent SSL. The SSL results from Groten and others (2016), Groten and others (2019), and this study document the variable nature of sediment loading in this section of the lower Minnesota River, with controlling variables such as low gradient, a wide flood plain, access to sloughs, and dredging that all affect how much sediment is stored and transported downstream into the Mississippi River at St. Paul, Minn. 


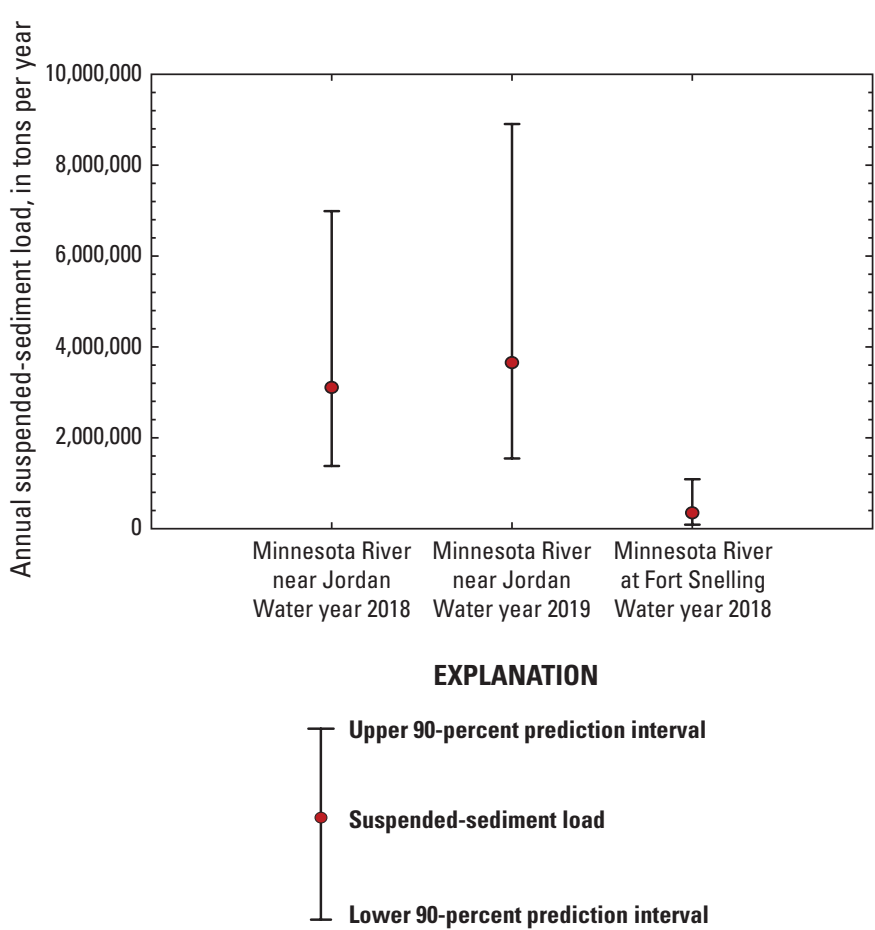

Figure 6. Estimated annual suspended-sediment loads from acoustic backscatter at two sites on the lower Minnesota River, water years 2018 through 2019.

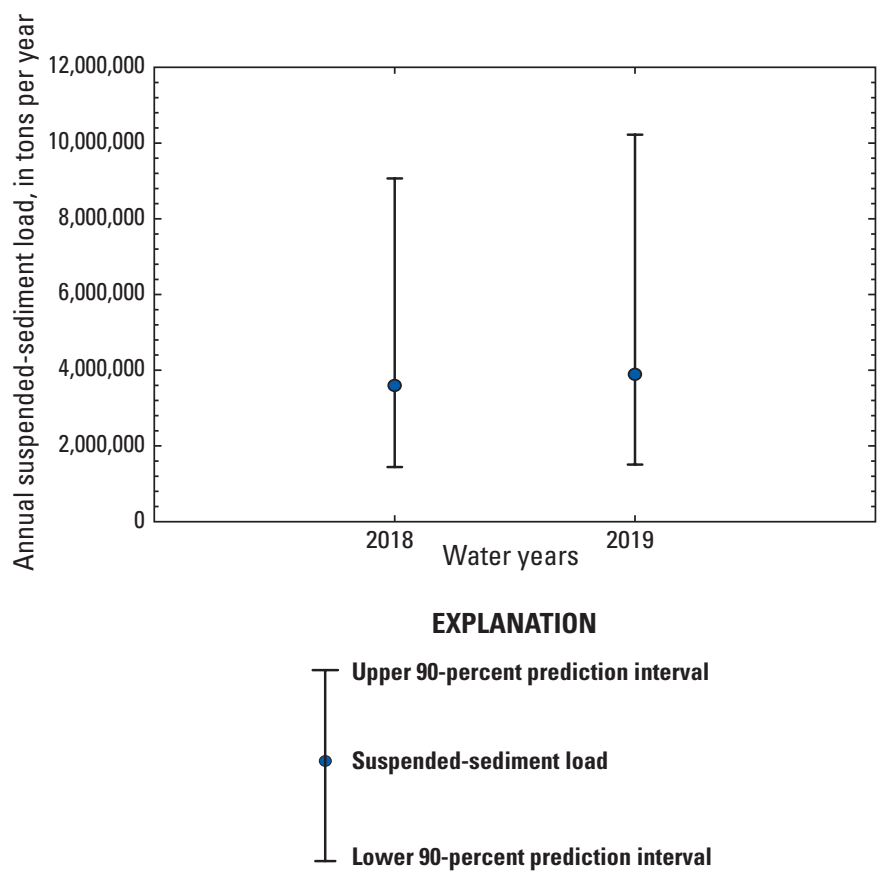

Figure 7. Estimated annual suspended-sediment loads from streamflow at the Minnesota River at Fort Snelling, water years 2018 through 2019.

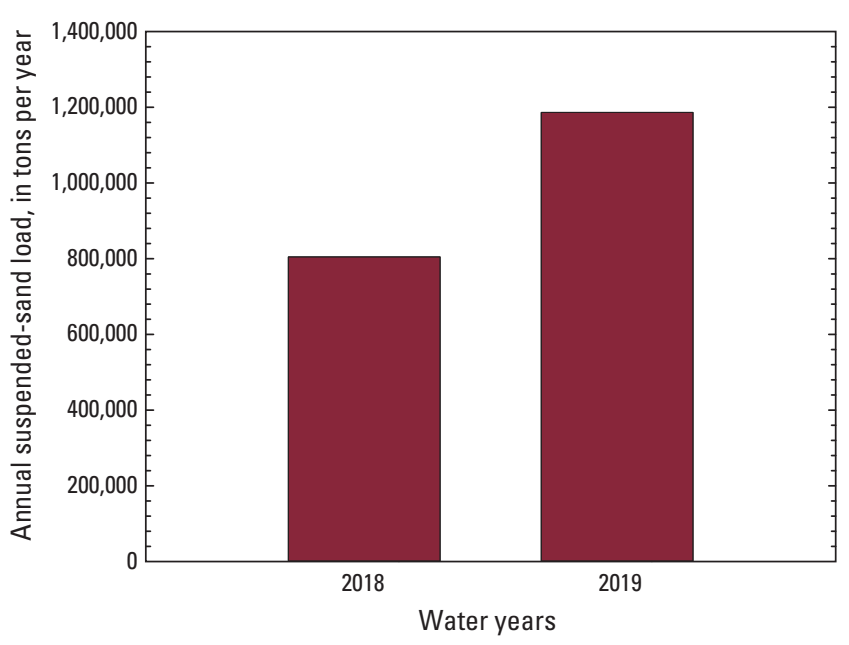

Figure 8. Estimated annual suspended-sand loads from streamflow at the Minnesota River at Fort Snelling, water years 2018 through 2019.

\section{Summary and Conclusions}

Streamgages that continuously monitor streamflow and other environmental parameters, such as acoustic backscatter, provide important data that are useful for making management decisions. The lower Minnesota River is used to support power production and commercial navigation, but excess sediment and the loss of a streamgage due to ice sheets in 2019 in the lower Minnesota at Fort Snelling State Park has hindered the abilities of resource managers to make future management decisions. Fortunately, another streamgage upstream of the destroyed streamgage was used to provide estimates of suspended sediment at the location of interest.

Simple linear regression models that used acoustic backscatter (Groten and others, 2019) to estimate SSC were redeveloped for the lower Minnesota River sites near Jordan and at Fort Snelling (Minnesota River at Fort Snelling, Minnesota [U.S. Geological Survey station 05330920, hereafter referred to as "Ft. Snelling"] and Minnesota River near Jordan, Minn. [U.S. Geological Survey station 05330000, hereafter referred to as "Jordan"]). The streamflow at Jordan was partitioned by the position on the streamflow hydrograph to account for hysteresis and changes in sediment delivery processes: low, rise, peak, high, and falling. Simple linear regression models were developed for each position on the streamflow hydrograph to estimate SSC and sand at Ft. Snelling from the streamflow at Jordan. Statistically significant models could not be developed for estimating SSC at the low streamflows and sand at high streamflows. The falling model was used to estimate SSC loads for the low streamflows, and the median sand value for the high streamflow category was used to estimate sand loads for the high streamflow category. 
The sand models were more uncertain than the SSC models, whereas the streamflow models were more uncertain than the acoustic models. Annual suspended-sediment loads described in this report and prior reports show the dynamic nature of sediment transport and storage in this section of the lower Minnesota River. The opportunity provided by having a streamgage near a destroyed streamgage was valuable for estimating streamflow and suspended sediment at a site of interest. These models can help with management decisions that are crucial in managing aquatic habitat, power production, and commercial navigation.

\section{References Cited}

American Society for Testing and Materials, 2000, Standard test methods for determining sediment concentration in water samples: West Conshohocken, Pa., American Society for Testing and Materials International, D3977-97, v. 11.02, Water (II), p. 395-400.

Davis, B.E., 2005, A guide to the proper selection and use of federally approved sediment and water-quality samplers: U.S. Geological Survey Open-File Report 2005-1087, 20 p. [Also available at https://doi.org/10.3133/ofr20051087.]

Domanski, M.M., Straub, T.D., and Landers, M.N., 2015, Surrogate Analysis and Index Developer (SAID) tool (version 1.0, September 2015): U.S. Geological Survey Open-File Report 2015-1177, 38 p., accessed June 26, 2020, at https:// doi.org/10.3133/ofr20151177.

Duan, N., 1983, Smearing estimate-A nonparametric retransformation method: Journal of the American Statistical Association, v. 78, no. 383, p. 605-610. [Also available at https://doi.org/10.2307/2288126.]

Edwards, T.K., and Glysson, G.D., 1999, Field methods for measurement of fluvial sediment: U.S. Geological Survey Techniques of Water-Resources Investigations, book 3, chap. C2, 89 p. [Also available at https://pubs.usgs.gov/ twri/twri3-c2/.]

Ellison, C.A., Groten, J.T., Lorenz, D.L., and Koller, K.S., 2016, Application of dimensionless sediment rating curves to predict suspended-sediment concentrations, bedload, and annual sediment loads for rivers in Minnesota (ver. 1.1, January 2020): U.S. Geological Survey Scientific Investigations Report 2016-5146, 68 p. [Also available at https://doi. org/10.3133/sir20165146.]

Engstrom, D.R., Almendinger, J.E., and Wolin, J.A., 2009, Historical changes in sediment and phosphorus loading to the upper Mississippi River-Mass-balance reconstructions from the sediments of Lake Pepin: Journal of Paleolimnology, v. 41, p. 563-588. [Also available at https://doi.org/ 10.1007/s10933-008-9292-5.]
Gray, J.R., and Gartner, J.W., 2009, Technological advances in suspended-sediment surrogate monitoring: Water Resources Research, v. 45, no. 4, accessed March 7, 2016, at https:// doi.org/10.1029/2008WR007063.

Groten, J.T., 2018, Suspended-sediment concentrations, acoustic data, and linear regression models for the Lower Minnesota River, Mississippi River, and Lake Pepin, 2015-2017: U.S. Geological Survey data release, accessed February 26, 2020, at https://doi.org/10.5066/F7542MXV.

Groten, J.T., 2021, Suspended-sediment and sand concentrations, streamflow, acoustic data, linear regression models, and loads for the Lower Minnesota River, 2012-2019: U.S. Geological Survey data release, https://doi.org/10.5066/ P9AIULOQ.

Groten, J.T., Ellison, C.A., and Hendrickson, J.S., 2016, Suspended-sediment concentrations, bedload, particle sizes, surrogate measurements, and annual sediment loads for selected sites in the lower Minnesota River Basin, water years 2011 through 2016: U.S. Geological Survey Scientific Investigations Report 2016-5174, 29 p., accessed February 26, 2020, at https://doi.org/10.3133/sir20165174.

Groten, J.T., Ziegeweid, J.R., Lund, J.W., Ellison, C.A., Costa, S.B., Coenen, E.N., and Kessler, E.W., 2019, Using acoustic Doppler velocity meters to estimate suspended sediment along the lower Minnesota and Mississippi Rivers: U.S. Geological Survey Scientific Investigations Report 2018-5165, 30 p. [Also available at https://doi.org/10.3133/ sir20185165.]

Guy, H.P., 1969, Laboratory theory and methods for sediment analysis: U.S. Geological Survey Techniques of Water Resources Investigations, book 5, chap. C1, 58 p. [Also available at https://pubs.usgs.gov/twri/twri5c1/.]

Helsel, D.R., Hirsch, R.M., Ryberg, K.R., Archfield, S.A., and Gilroy, E.J., 2020, Statistical methods in water resources: U.S. Geological Survey Techniques and Methods, book 4, chap. A3, 458 p. [Also available at https://doi.org/10.3133/ tm4a3.]

Landers, M.N., Straub, T.D., Wood, M.S., and Domanski, M.M., 2016, Sediment acoustic index method for computing continuous suspended-sediment concentrations: U.S. Geological Survey Techniques and Methods, book 3, chap. C5, 63 p., accessed August 9, 2020, at https://doi.org/ $10.3133 / \mathrm{tm} 3 \mathrm{c} 5$.

Landers, M.N., and Sturm, T.W., 2013, Hysteresis in suspended sediment to turbidity relations due to changing particle size distributions: Water Resources Research, v. 49, no. 9, p. 5487-5500, accessed March 11, 2016, at https:// doi.org/10.1002/wrcr.20394. 
Lenhart, C.F., Titov, M.L., Ulrich, J.S., Nieber, J.L., and Suppes, B.J., 2013, The role of hydrologic alteration and riparian vegetation dynamics in channel evolution along the lower Minnesota River: Transactions of the ASABE, v. 56, no. 2, p. 549-561. [Also available at https://doi.org/ $10.13031 / 2013.42686$.]

Minnesota Pollution Control Agency, 2009, Total maximum daily load (TMDL) projects: Minnesota Pollution Control Agency web page, accessed May 12, 2020, at https://www. pca.state.mn.us/water/total-maximum-daily-load-tmdl-projects.

Minnesota Pollution Control Agency, 2015, Sediment reduction strategy for the Minnesota River Basin and South Metro Mississippi River: Minnesota Pollution Control Agency, 61 p., accessed May 12, 2020, at https://www.pca. state.mn.us/sites/default/files/wq-iw4-02.pdf.

Porterfield, G., 1972, Computation of fluvial-sediment discharge: U.S. Geological Survey Techniques of Water Resources Investigations, book 3, chap. C3, 65 p. [Also available at https://pubs.usgs.gov/twri/twri3-c3/.]

Topping, D.J., and Wright, S.A., 2016, Long-term continuous acoustical suspended-sediment measurements in riversTheory, application, bias, and error: U.S. Geological Survey Professional Paper 1823, 98 p. [Also available at https://doi. org/10.3133/pp1823.]

U.S. Army Corps of Engineers, 2001, Channel maintenance management plan, Upper Mississippi River navigation system, St. Paul District: U.S. Army Corps of Engineers, St. Paul District, 28 p., accessed May 25, 2020, at https://www. mvp.usace.army.mil/Portals/57/docs/Navigation/CMMP/ GenInfo.pdf.
U.S. Army Corps of Engineers, 2006, Sedimentation in the Upper Mississippi River basin: U.S. Army Corps of Engineers, St. Louis District, 143 p., accessed May 25, 2020, at http://mvswc.mvs.usace.army.mil/arec/Documents/Geomorphology/Sedimentation_Upper_Mississippi_River_Basin_ 2.pdf.

U.S. Army Corps of Engineers, 2007, Dredged material management plan/environmental assessment, Minnesota River: U.S. Army Corps of Engineers, St. Paul District, 285 p., accessed May 25, 2020, at https://www.mvp.usace.army. mil/Portals/57/docs/Navigation/River\%20Resource $\% 20$ Forum/MN_River_DMMP_2007_Final.pdf.

U.S. Army Corps of Engineers, 2011, Upper Mississippi River land use allocation plan: U.S. Army Corps of Engineers, St. Paul District, 86 p., accessed July 13, 2020, at http://www. mvp.usace.army.mil/Portals/57/docs/Recreation/UpperMissLandUse/UMRL_Allocation_Plan.pdf.

U.S. Geological Survey, 2020, USGS water data for the Nation: U.S. Geological Survey National Water Information System database, accessed July 16, 2020, at https://doi.org/ 10.5066/F7P55KJN.

Wood, M.S., 2014, Estimating suspended sediment in rivers using acoustic Doppler meters: U.S. Geological Survey Fact Sheet 2014-3038, 4 p., accessed March 11, 2016, at https:// doi.org/10.3133/fs20143038. 
For more information about this publication, contact: Director, USGS Upper Midwest Water Science Center 2280 Woodale Drive

Mounds View, MN 55112

763-783-3100

For additional information, visit: https://www.usgs.gov/centers/ umid-water

Publishing support provided by the

Rolla Publishing Service Center 
